ISSN 1817-7204(Print)

ISSN 1817-7239(Online)

UDK 635.657:631.524.6(477)

https://doi.org/10.29235/1817-7204-2021-59-2-198-204

Received 19.08.2020

Поступила в редакцию 19.08.2020

\author{
Nadiia A. Vus ${ }^{1}$, Antonina A. Vasylenko ${ }^{1}$, Lyubov K. Kobyzeva ${ }^{1}$, Olha N. Besuhla ${ }^{1}$, \\ Olha V. Antziferova ${ }^{1}$, Sergiy I. Sylenko ${ }^{2}$ \\ ${ }^{1}$ Plant Production Institute named after V.Ya. Yuriev of NAAS, Kharkiv, Ukraine \\ ${ }^{2}$ Ustymivska Experimental station of the Plant Production \\ Institute named after V.Ya. Yuriev of NAAS, Ustymivka village, Hlobyno District, Poltava Region, Ukraine
}

\title{
OIL CONTENT IN CHICKPEA SEEDS OF THE NATIONAL COLLECTION OF UKRAINE
}

Abstract: Chickpea (Cicer arietinum L.) is an important legume crop grown and consumed worldwide. Oil content in chickpea seeds ranges from $4 \%$ to $7 \%$ according to various data sources. Considering the interest of breeders in this issue, as well as for the purpose of inventory of the presented chickpea genetic material in the collection of the National Center for Plant Genetic Resources of Ukraine, these studies were carried out. Field experiments were carried out in 2016-2018 in the scientific crop rotation of the Plant Production Institute n.a. V. Ya. Yuriev of NAAS (Kharkiv, Ukraine). 43 samples (21 - kabuli type and 22 - desi type) of different ecological and geographical origin were studied. Oil content in chickpea seeds was determined using gravimetric method of S. V. Rushkovsky (Yermakov, 1987) in the laboratory for genetics, biotechnology and quality of the Plant Production Institute n.a. V. Ya. Yuriev of NAAS. On average, over the years of study, in the kabuli type accessions, the oil content level in the seeds made $7.08 \%$; for accessions $-6.05 \%$. The range of variability of this trait for the kabuli chickpea ranged from $5.22 \%$ to $8.69 \%$, and for desi - from $4.40 \%$ to $7.26 \%$. A low variability of the studied trait was noted for both the kabuli $(V=6.88-15.04 \%)$ and for desi $(V=8.98-14.15 \%)$ chickpea cultivars. The advantage in terms of oil content in seeds, regardless of the growing conditions, was retained for the kabuli type. The accessions with the maximum level of the "oil content in seeds" trait manifestation were selected as "reference" for each type: for kabuli - variety Pamyat (Ukraine) - 7.95 \%, for desi - Yarina (Ukraine) - $7.13 \%$. The best oil-bearing chickpea samples can be used in specialized programs to create new genotypes with a higher oil content in seeds.

Keywords: legumes, Cicer arietinum L., National Center for Plant Genetic Resources of Ukraine, selection, sample, kabuli morphotype, desi morphotype, oil content in seeds

For citation: Vus N. A., Vasylenko A. A., Kobyzeva L. K., Besuhla O. N., Antziferova O. V., Sylenko S. I. Oil content in chickpea seeds of the national collection of Ukraine.Vestsi Natsyyanal'nay akademii navuk Belarusi. Seryya agrarnykh navuk = Proceedings of the National Academy of Sciences of Belarus. Agrarian series, 2021, vol. 59, no 2, pp. $198-204$. https://doi.org/10.29235/1817-7204-2021-59-2-198-204

\section{Н.А. Вус ${ }^{1}$, А. А. Василенко ${ }^{1}$,.Н. Кобызева ${ }^{1}$, О.Н. Безуглая ${ }^{1}$, О. В. Анциферова ${ }^{1}$, С. И. Силенко}

\author{
${ }^{1}$ Институт растениеводства им. В. Я. Юрьева Национальной академии аграрных наук Украины,, Харьков, Украина \\ ${ }^{2}$ Устимовская опытная станция Института растениеводства им. В. Я. Юрьева Национальной академии аграрных \\ наук Украинь, с. Устимовка, Глобинский район, Полтавская обл., Украина
}

\section{СОДЕРЖАНИЕ МАСЛА В СЕМЕНАХ НУТА НАЦИОНАЛЬНОЙ КОЛЛЕКЦИИ УКРАИНЫ}

Аннотация: Нут (Cicer arietinum L.) является важной зернобобовой культурой, которую выращивают и потребляют во всем мире. Содержание масла в семенах нута по различным данным колеблется от 4 до 7 \%. Учитывая интерес к данному вопросу со стороны селекционеров, а также с целью инвентаризации представленного генетического материала нута в коллекции Национального центра генетических ресурсов растений Украины были проведены настоящие исследования. Полевые опыты были проведены в 2016-2018 гг. в научном севообороте Института растениеводства им. В.Я. Юрьева (Харьков, Украина). Исследовали 43 образца (21 тип kabuli и 22 типа - desi) разного эколого-географического происхождения. Содержания масла в семенах нута определяли гравиметрическим методом С.В. Рушковского (Ермаков, 1987) в лаборатории генетики, биотехнологии и качества Институра растениеводства им. В. Я. Юрьева НААН. В среднем за годы изучения у образцов морфотипа kabuli содержание масла в семенах составило 7,08 \%; у образцов типа desi - 6,05 \%. Диапазон изменчивости данного признака для морфотипа kabuli колебался от 5,22 до 8,69 \%, a у desi - от 4,40 до 7,26 \%. Отмечена невысокая вариативность изучаемого признака как для морфотипа kabuli $(V=6,88-15,04 \%)$, так и для desi $(V=8,98-14,15$ \%). Преимущество по содержанию масла в семенах, независимо от условий вегетации, сохранялось за морфотипом kabuli. В качестве «эталонных» для каждого из морфотипов выделены образцы с максимальным уровнем проявления признака «содержанием масла в семенах»: для морфотипа kabuli - сорт Память (Украина) - 7,95 \%, для desi - сорт Ярина (Украина) - 7,13 \%. Лучшие по масличности образцы нута могут быть использованы в специализированных программах для согдания новых генотипов с повышенным содержанием жира в семенах.

Ключевые слова: зернобобовые культуры, Cicer arietinum L., Национальныйо центр генетических ресурсов растений Украины, селекция, образец, морфотип kabuli, морфотип desi, содержанием масла в семенах 
Для цитирования: Содержание масла в семенах нута Национальной коллекции Украины / Н. А. Вус, А. А. Василенко, Л.Н. Кобызева, О. Н. Безуглая, О. В. Анциферова, С. И. Силенко // Вес. Нац. акад. навук Беларусі. Сер. аграр. навук. - 2021. - Т. 59, №2. - С. 198-204. https://doi.org/10.29235/1817-7204-2021-59-2-198-204

Introduction. Chickpea (Cicer arietinum L.) is an important grain legume, which is grown and consumed worldwide and will gain in importance with climate change. The production and consumption of chickpea is steadily increasing. Ranked third in the world for production among legumes, chickpea is an important source of protein in densely populated but poor regions of Asia and Africa [1]. Two market chickpea types: desi and kabuli, are grown in the world, differing in the morphological characteristics of seeds. About $75 \%$ of world chickpea production is Desi, angular and dark. They are grown mainly in Asia and Ethiopia. Kabuli seeds are beige in color and round in shape. They are usually grown in the Mediterranean and Mexico [15].

It is a good source of carbohydrates and proteins. The presence of lipids in chickpea seeds increases their nutritional value. Among legumes, peanut (Arachis hypogaea L.), soybean (Glycine max (L.) Merr.) and winged bean (Psophocarpus tetragonolobus (L.) DC.) are distinguished due to lipid content, which is $49.7 \%, 21.3 \%$ and $16.8 \%$, respectively [2]. Most of the legume seeds contained a low level of oil content, from $1.7 \%$ in horse bean (Vicia faba L.), to $4.5 \%$ in kidney bean (Phaseolus coccineus L.) [3]. As different sources claim, the oil content in chickpea seeds varies from $4 \%$ to $7 \%$; of the total amount of fatty acids in chickpea oil, saturated fatty acids account for $13 \%$, monounsaturated fatty acids - for $20 \%$, and polyunsaturated ones - for $67 \%$. Among the unsaturated fatty acids, linoleic (43.29\%) and oleic $(21.84 \%)$ prevail in chickpea seeds, and palmitic $(9.22 \%)$ prevail among the saturated fatty acids $[2,4,5,6]$. The content of these fatty acids can vary significantly depending on weather conditions. However, the influence of the genotype and genotype-environment interactions are equally important [7]. The chickpea oil contains B-sitosterol, campesterol and stigmasterol, which are important sterols [8]. There is a significant negative correlation between the oil content and content of phytin phosphorus compounds with anti-nutritional properties [9]. An increase in the oil content in the seeds of legume crops by breeding work significantly improves their nutritional quality. Thus, in pea, using the current genetic diversity, breeders have achieved a level of oil content in seeds of $7.7 \%$, while in the most common smooth-seeded varieties its level does not exceed $2.0 \%$ [10]. The study of the national collection of genetic resources allows you to expand the range of use of genetic material in special breeding. So, in peas, genetically determined natural starch-modifying mutations are associated with the content and quality of oil [11].

Among the most widely used legumes in Ukraine (pea, common bean, chickpea and lentil), chickpea are characterized by the highest oil content, the lowest insoluble fiber and the absence of soluble dietary fiber [12].

The potential of chickpea for healthy nutrition is especially high. Polyunsaturated fatty acids (such as linoleic acid) actively reduce serum cholesterol; monounsaturated ones (for example, oleic acid) do not have an independent effect on the level of serum cholesterol, as saturated fatty acids (for example, palmitic acid) play the main role in the metabolism of this substance, increasing its level. The presence of polyunsaturated fatty acids creates the conditions for synthesis of prostaglandins, which prevent alpha lipoprotein (HDL) cholesterol from concentrating on of blood vessel walls [5]. For example, chickpea is included in special diets both for prophylaxis and for treatment of cardiovascular diseases, type 2 diabetes, diseases of the digestive system, and some types of cancer [8]. The specific chemical composition of chickpea (carbohydrates $48 \%$; protein - $28 \%$; fat - $4.5 \%$ ) is most suitable for the production of meat and vegetable precooked foods. Patty cakes containing 20-25\% of chickpea flour have been developed for elderly nutrition [4].

Chickpea has become the main ingredient in follow-on formula for baby food that meets WHO / FAO complementary feeding requirements as well as EU rules for such follow-on formula with a minimum addition of oils, minerals and vitamins. Chickpeas have been used as a major source of carbohydrates and protein, making such formula more economical and affordable for low-income countries without compromising nutritional quality [13].

Adding chickpea flour to foods such as bread, snacks and chips increases their nutritional value by enriching them with protein and lowering anti-nutrients such as acrylamide [14].

Publications by researchers from India and Pakistan, countries where chickpea is the basis of the diet, dominate in the literature on the issue. In Ukraine, studies of the oil content in chickpea seeds are episodic [16, 17], and the core chickpea collection of the National Center for Plant Genetic Resources of Ukraine (NCPGRU) was not evaluated for this trait. Given the interest in this issue from breeders and 
consumers, as well as for the purpose of inventorying the available genetic material of chickpea from the NCPGRU's core collection, this study was designed and conducted. There were also issues of a scale for assessing the oil content in seeds, identification of check accessions for further studies and sources of high oil content in seeds for breeding, which became our objectives.

Material and Methods. In 2016-2018, the oil content in chickpea seeds from the NCPGRU's core collection was analyzed for the first time. In 2016, 24 accessions were studied 12 kabuli (with light seeds) and desi (with dark seeds) accessions of different eco-geographical origin. These accessions have been investigated at the NCPGRU for many years, and some of them were previously chosen as check accessions for different valuable traits, such as yield capacity, resistance to ascochytosis, seed size, early ripening, high protein content, cooking property, etc. [18]. In 2017- 2018, the assortment of the studied accessions was expanded to 43 accessions ( 21 belonged to the kabuli-type and 22 - to the desi-type) due to local accessions of different origin.

According to the State Standard for identifying sources of valuable traits in the NCPGRU's collections, accessions whose values are by $\geqslant 15 \%$ higher than the average across the sample are distinguished as sources ${ }^{1}$.

The field experiments were carried out in the scientific crop rotation of the Plant Production Institute named after V.Ya. Yuriev, Kharkiv, Ukraine in 2016-2018. The forecrop was winter wheat. The field experiments were conducted in accordance with the "Guidelines for Studying the Genetic Resources of Grain Legumes" (2016) ${ }^{2}$.

The oil content in chickpea seeds was determined by S. V. Rushkovsky's gravimetric method ${ }^{3}$ in the Laboratory of Genetics, Biotechnology and Guality of the Plant Production Institute of named after V.Ya. Yuriev of NAAS.

The weather conditions during the vegetation periods of the 3 study years varied significantly. 2016 was characterized by waterlogging during the chickpea flowering and ripening periods (June-August): the precipitation amount was $143.7 \mathrm{~mm}$, which is by $60.6 \%$ higher than the multi-year average for this period, while both 2017 and 2018 were hot and dry, with $43 \%$ and $60.9 \%$ of rainfall related to the multi-year average, respectively. In 2018, the average daytime temperature in June-August reached 29.6-35.5 ${ }^{\circ} \mathrm{C}$ and was accompanied by heavy rains during the seed setting and filling. Of the 3 study years, 2016 was unfavorable for the chickpea growth and development, and 2017 and 2018 were closer to the optimum for this crop, although they were marked by high temperature and drought.

Results: The 2016 results showed that the average oil content across the sample of chickpea seeds was $7.72 \%$, ranging 6.79 to $8.57 \%$ in the kabuli accessions and 5.02 to $7.26 \%$ in the desi ones (Table 1), which is significantly higher than the values reported by other researchers. For example, Shah et al. reported that the oil content in chickpea seeds from Pakistan was $3.54 \%$ [22]; in Avola et al.'s publication it was $4.36 \%$ for Italian accessions [23].

Seven out of the 12 kabuli accessions investigated in 2016 had an oil content within the average across the test sample (7.16\%), and in 2 accessions the values exceeded the average by more than $15 \%$ : Ukrainian cultivars Dniprovskyi Vysokoroslyi (8.27\%) and Smachnyi (8.52 \%). As to the desi-type, 3 accessions had the intermediate contents: CDC Anna (7.26 \%), Krasnokutskiy 123 (7.21\%) and Koloryt (7.11\%). None of the desi accessions exceeded the average by more than $15 \%$.

The three-year study (2016-2018) of the oil content in chickpea seeds in the conditions of the Eastern Forest-Steppe of Ukraine showed that in this test sample the average was $7.08 \%$ and $6.05 \%$ across the kabuli and desi accessions, respectively (Table 2).

The oil content range in chickpea seeds over the study years was $5.22 \%$ to $8.69 \%$ and $4.40 \%$ to $7.26 \%$ for the kabuli and desi types, respectively. The oil content in seeds across the entire sample ranged $4.40 \%$ to $8.69 \%$. It should be noted that in 2017 and 2018, compared with 2016, the oil content range in seeds expanded significantly, which can be attributed both to an increase in the number of accessions in the

\footnotetext{
${ }^{1}$ State Standard of Ukraine 7066.2009. Genetic resources of plants. Terms and definitions. Kyiv, Derzhspozhyvstandart Ukrainy, 2010. (in Ukrainian).

${ }^{2}$ Kobyzeva L. N., Bezugla O. M., Silenko S. I., Kolotilov V. V., Sokol T. V., Dokukina K. I., Vasilenko A. O., Bezuglii I. M., Vus N. O. Guidelines for studying the genetic resources of grain legumes. Kharkiv, Stil'-Izdat Publ., 2016. 84 p. (in Ukrainian).

${ }^{3}$ Ermakov A. I. (ed.). Methods of biochemical studies on plants. 3nd ed. Leningrad, Agropromizdat Publ., 1987. 430 p. (in Russian).
} 
$\mathrm{T}$ a $\mathrm{b} 1 \mathrm{e}$ 1. Oil Content in Chickpea Seeds Harvested in 2016

\begin{tabular}{|c|c|c|c|c|c|c|c|}
\hline $\begin{array}{l}\text { No in the National } \\
\text { Catalogue of } \\
\text { Ukraine }\end{array}$ & Name & $\begin{array}{l}\text { Country } \\
\text { of origin }\end{array}$ & $\begin{array}{c}\text { Oil content } \\
\%\end{array}$ & $\begin{array}{c}\text { No in the National } \\
\text { Catalogue of Ukra } \\
\text { ine }\end{array}$ & Name & Country of origin & $\begin{array}{c}\text { Oil } \\
\text { content, } \%\end{array}$ \\
\hline \multicolumn{4}{|l|}{ Rabuli } & \multicolumn{4}{|l|}{ Desi } \\
\hline UD0500417 & Smachnyi & Ukraine & 8.52 & UD0500723 & CDC Anna & Canada & 7.26 \\
\hline UD0500444 & $\begin{array}{l}\text { Dniprovskyi } \\
\text { Vysokoroslyi }\end{array}$ & Ukraine & 8.27 & UD0500101 & $\begin{array}{l}\text { Krasnokutskiy } \\
123\end{array}$ & Russia & 7.21 \\
\hline UD0500736 & Pamiat & Ukraine & 8.18 & UD0500429 & Koloryt & Ukraine & 7.18 \\
\hline UD0502113 & Jamila & Azerbaijan & 8.04 & UD0501172 & KР 3990 & Ukraine & 6.93 \\
\hline UD0500424 & Rozanna & Ukraine & 6.81 & \begin{tabular}{|l|} 
UD0500425 \\
\end{tabular} & \begin{tabular}{|l|} 
Aleksandryt \\
\end{tabular} & Ukraine & 6.81 \\
\hline UD0501194 & Dobrobut & Ukraine & 7.91 & UD0501164 & Pehas & Ukraine & 6.67 \\
\hline UD0500762 & Zavolzhskiy & Russia & 7.85 & UD0500495 & E 100 & Greece & 6.64 \\
\hline UD0500864 & Flip 99-55C & Siria & 7.70 & UD0500719 & Sovkhoznyy 14 & Russia & 6.56 \\
\hline UD0500196 & - & Azerbaijan & 7.66 & UD0500494 & R 919 & Russia & 6.55 \\
\hline UD0501200 & Slobozhanskyi & Ukraine & 7.56 & UD0500422 & Cicer rotundum & Czech Republic & 6.42 \\
\hline UD0502093 & - & Ukraine & 7.42 & UD0500263 & - & Ukraine & 6.29 \\
\hline UD0500689 & Skorospelka & Russia & 6.79 & UD0500022 & - & Georgia & 5.02 \\
\hline \multicolumn{3}{|l|}{ Mean } & 7.72 & \multicolumn{3}{|l|}{ Mean } & 6.60 \\
\hline \multicolumn{3}{|c|}{ Coefficient of variation, $\%$} & 6.88 & \multicolumn{3}{|c|}{ Coefficient of variation, $\%$} & 8.98 \\
\hline \multicolumn{3}{|l|}{ Variance } & 0.28 & \multicolumn{3}{|l|}{ Variance } & 0.36 \\
\hline
\end{tabular}

T a b 1 e 2. Oil Content in Chickpea Seeds of the Two Types

\begin{tabular}{|l|c|c|c|c|c|c|c|c|c|c|c|c|}
\hline \multirow{3}{*}{ Year } & \multicolumn{10}{|c|}{ Oil Content, \% } \\
\cline { 2 - 15 } & \multicolumn{4}{|c|}{ Kabuli } & \multicolumn{4}{|c|}{ Desi } & \multicolumn{4}{|c|}{ Total } \\
\cline { 2 - 14 } & Min & Max & Mean & CV, \% & Min & Max & Mean & CV, \% & Min & Max & Mean & CV, \% \\
\hline 2016 & 6.79 & 8.52 & 7.73 & 6.88 & 5.02 & 7.26 & 6.63 & 8.98 & 5.02 & 8.52 & 7.18 & 10.98 \\
\hline 2017 & 5.74 & 8.69 & 6.89 & 10.98 & 4.70 & 7.20 & 6.04 & 12.26 & 4.70 & 8.69 & 6.43 & 13.26 \\
\hline 2018 & 5.22 & 8.65 & 6.62 & 15.04 & 4.40 & 7.07 & 5.47 & 14.15 & 4.40 & 8.65 & 5.99 & 17.41 \\
\hline Mean & & & 7.08 & & & & 6.05 & & & & 6.53 & \\
\hline
\end{tabular}

sample and to a possible influence of the plant vegetation conditions. Thus, in 2016 the oil co-tent was for the kabuli-type was $6.79 \%-8.52 \%$, and in 2017 and $2018-5.74 \%-8.69 \%$ and $5.22-8.65 \%$, respectively. The same trend was noted for the desi-type: in 2016 the oil content amounted to $5.02 \%-7.26 \%$, and in 2017 and 2018 this parameter was in the range of $4.70-7.20 \%$ and $4.40 \%-7.07 \%$, respectively.

Analysis of the 2016 data gave a low coefficient of variation of the "oil content in seeds" trait in the kabuli $(\mathrm{CV}=6.88 \%)$ and desi $(\mathrm{CV}=8.98 \%)$ accessions, which can be attributed either to a high homogeneity of the sample or to a consequence of its small size and effects of the weather conditions. Avola et al. (2012) noted that the oil content varied slightly in different accessions, but increased significantly during seed cooking [23]. Ukrainian researchers also reported a weak variability in the trait [17]. When the size of the sample increased to 43 accessions in 2017 - 2018, the coefficient of variation rose for the both types, but it did not fall outside of the average limits.

Working with genetic resources, one should evaluate large numbers of collection accessions, which requires a scale with a variability range of the trait under investigation. To develop such a scale, we reviewed literature data published by researchers from different countries (Table 3).

The minimum oil content in chickpea seeds was noted in Pakistan (3.54\% [22]) and in Italy (4.36\% [23]). The maximum was $8.00 \%$ in Ukraine [16] and $9.01 \%$ in Argentina [32]. Within this range, the scale gradations were calculated for assessing the oil content in chickpea seeds from the NCPGRU's core collection: Very low - below 5.00 \%; Low - 5.00-5.99 \%; Moderate - 6.00-6.99 \%; High - 7.00-8.00 \%; Very high - above $8.00 \%$.

After developing the scale, it became possible to evaluate chickpea accessions of the core collection of the National Center for Plant Genetic Resources of Ukraine for the oil content (Fig. 1). 
202 Proceedings of the National Academy of Sciences of Belarus, agrarian series, 2021, vol. 59, no. 2, pp. 198-204

$\mathrm{T}$ a $\mathrm{b} 1 \mathrm{e}$ 3. Oil Content in Chickpea Seeds from Different Countries (according to published data)

\begin{tabular}{|l|c|c|c|}
\hline \multirow{2}{*}{ Country } & \multicolumn{2}{|c|}{ Oil content, \% } & \multirow{2}{*}{ Reference } \\
\cline { 2 - 3 } & Rabuli & Desi & \\
\hline Ukraine & $7.3-8.0$ & 6.5 & {$[16]$} \\
\hline Ukraine & \multicolumn{2}{|c|}{5.8} & {$[17]$} \\
\hline Italy (Sicily) & 4.36 & - & {$[23]$} \\
\hline Italy (Sicily) & 6 & - & {$[24]$} \\
\hline Makedonia & $4.44-5.16$ & - & {$[25]$} \\
\hline Turkey & $4.45-6.11$ & - & {$[26]$} \\
\hline Ethiopia & - & 5.88 & {$[27]$} \\
\hline Pakistan & 3.54 & - & {$[22]$} \\
\hline Pakistan & 4.5 & 5.7 & {$[28]$} \\
\hline Pakistan & - & $5.88-6.87$ & {$[29]$} \\
\hline India & - & $4.18-4.92$ & {$[30]$} \\
\hline Canada & 5,5 & 3,6 & {$[31]$} \\
\hline Argentina & $5,68-9,01$ & - & {$[32]$} \\
\hline
\end{tabular}

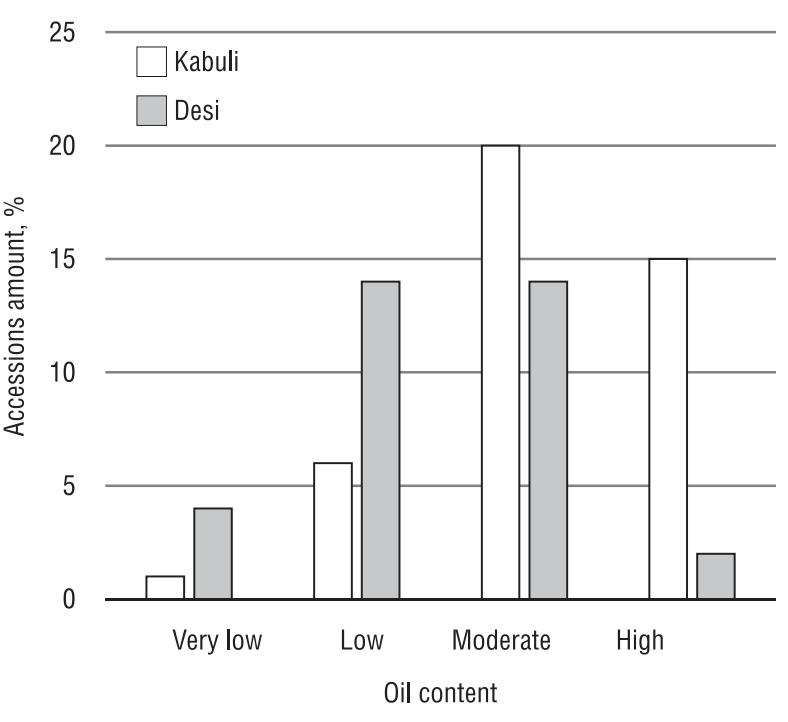

Fig. 1. Comparison of Chickpea Types According to the Oil Content in Seeds Scale

As a result, the accessions under investigation were categorized according to this scale. It was found that among the kabuli accessions, accessions with a moderate (10 accessions, $48 \%$ of the entire kabuli sample) and high ( 8 accessions; $36 \%$ ) oil content in seeds were overwhelming. As to the desi-type, accessions with a low and moderate oil content in seeds were the most numerous (9 accessions of each type; $41 \%$ ).

The high stability of the trait under investigation allowed us to identify sources of high oil content in seeds. These accessions can be used in specialized breeding programs to create new genotypes with high oil content in chickpea seeds. T. M. Shah noted a more conspicuous increase in oil level when parental pairs of different morphological types ( $k a b u l i$ and desi) are crossed than when accessions belonging to the same morphological type are crossed [28]. Therefore, selection of accessions - sources of high oil content belonging to different types is a pre-requisite for further breeding to improve the nutritional qualities of chickpea.

A two-year study of accessions is sufficient to identify sources of high oil content in seeds. In 20172018, seeds of the kabuli accessions contained $5.78 \%-7.95 \%($ mean $=6.95 \%)$ of oil. A high oil content ( $7.00-7.99 \%$ ) was recorded for 10 test kabuli accessions (47.62 \%), which we recognized as sources of high oil content. These are Pamiat (Ukraine), NEC 2184 (Iran), UD0502111 (Russia) and others. There were no accessions with very high (above $8.00 \%$ ) oil content. The maximum oil level during the two study years was observed in Pamiat (Ukraine; 7.95 \%), NEC 2184 (Iran; $7.79 \%$ ) and UD0502111 (Russia; $7.77 \%$ ).

As to the desi-type, the average oil content for the two study years was $5.89 \%$. A high oil level was only observed in 1 accession - Yaryna (Ukraine) - $7.13 \%$. The most of the desi accessions had a moderate (40.91\% of the sample) or a low (50\%) content of oil. Among the studied desi accessions,

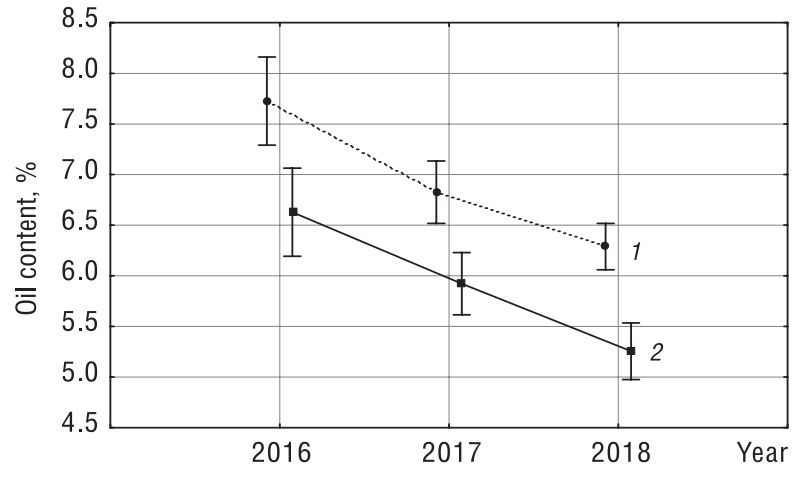

Fig. 2. Oil Content in Chickpea Seeds Depending the Year Conditions ( 1 - kabuli; 2 - desi). Oil content (\%), Year, Type, LSM means, Hypothesis decomposition, Vertical bars denote $95 \%$ confidence intervals
2 accessions with high oil content in seeds were identified: Yaryna (7.13\%) and Koloryt (6.91\%); the both cultivars have been bred in Ukraine and can be sources of this trait in the desi-type.

The accessions with the maximum expression of the trait of interest were selected as check accessions for their morphological types: cultivar Pamiat (Ukraine) for the kabuli-type and cultivar Yaryna (Ukraine) for the desi-type.

Unidirectional and similar fluctuations in the oil content were noted in both kabuli and desi accessions, depending on the year conditions (Fig. 2).

We found that the kabuli-type is superior to the desi-type in terms of oil content in seeds, regardless of the growing conditions. 
Conclusions. Thus, our studies showed that the chickpea accessions of the NCPGRU's collection had a high oil content in seeds, which increases their value for breeding programs to develop new food cultivars for a balanced diet.

Valuable sources of high oil content in seeds (Pamiat (Ukraine), NEC 2184 (Iran) and UD0 502111 (Russia) belonging to the kabuli type as well as Yaryna and Koloryt (Ukraine) belonging to the desi-type were identified. We recommend including them in breeding programs to develop new chickpea cultivars.

We experimentally developed the scale that is recommended for classification of chickpea accessions by oil content in seeds.

\section{References}

1. Merga B., Haji J. Economic importance of chickpea: Production, value, and world trade. Cogent Food \& Agriculture, 2019, vol. 5, no. 1, p. 1615718. https://doi.org/10.1080/23311932.2019.1615718

2. Arora S. K. (ed.). Chemistry and biochemistry of legumes. London, Edward Arnold, 1983. 359 p.

3. Grela E. R., Günter K. D. Fatty acid composition and tocopherol content of some legume seeds. Animal Feed Science and Technology, 1995, vol. 52, no. 3-4, pp. 325-331. https://doi.org/10.1016/0377-8401(94)00733-P

4. Sharipova T. V., Mandro N.M. Prospects of using the grain legume chickpea in production of meat-vegetable foods for elderly nutrition. Vestnik Altaiskogo gosudarstvennogo agrarnogo universiteta = Bulletin of Altai State Agricultural University, 2012, no. 12 (98), pp. 102-106 (in Russian).

5. Pashchenko L.P. Development of technique of bread, enriching seeds of a chick pea. Uspekhi sovremennogo estestvoznaniya $=$ Advances in Current Natural Sciences, 2009, no. 1, pp. 24-38 (in Russian).

6. Wood J. A., Grusak M. A. Nutritional value of chickpea. Chickpea breeding and management. Wallingford, 2007, pp. 101142. https://doi.org/10.1079/9781845932138.005

7. Gül M. K., Egesel C. Ö., Turhan H. The effects of planting time on fatty acids and tocopherols in chickpea. European Food Research and Technology, 2008, vol. 226, no. 3, pp. 517-522. https://doi.org/10.1007/s00217-007-0564-5

8. Jukanti A. K., Gaur P. M., Gowda C.L. L., Chibbar R. N. Nutritional quality and food benefits of chickpea (Cicer arietinum L.): a review. British Journal of Nutrition, 2012, vol. 108, no. S1, pp. S11-S26. https://doi.org/10.1017/s0007114512000797

9. Chitra U., Vimala V., Singh U., Geervani P. Variability in phytic acid content and protein digestibility of seed legumes. Plant Foods for Human Nutrition, 1995, vol. 47, no. 2, pp. 163-172. https://doi.org/10.1007/bf01089266

10. Wang T. L., Hadavizideh A., Harwood A., Welham T. J., Harwood W. A., Faulks R., Hedley C.L. An analysis of seed development in Pisum sativum. XIII. The chemical induction of storage product mutants. Plant Breeding, 1990, vol. 105, no. 4, pp. 311320. https://doi.org/10.1111/j.1439-0523.1990.tb01290.x

11. Vasilenko A. A., Tymchuk S. M., Pozdnyakov V. V., Suprun O. G., Antsiferova O. V., Bezuglyi I. M. Content and fatty acid composition of oil in the seeds of pea starch-modifying mutants. Zernobobovye i krupyanye kul'tury = Legumes and Groat Crops, 2017, no. 3 (23), pp. 33-39 (in Russian).

12. De Almeida Costa G. E., Da Silva Queiroz-Monici K., Pissini Machado Reis S. M., De Oliveira A. C. Chemical composition, dietary fibre and resistant starch contents of raw and cooked pea, common bean, chickpea and lentil legumes. Food Chemistry, 2006, vol. 94, no. 3, pp. 327-330. https://doi.org/10.1016/j.foodchem.2004.11.020

13. Malunga L. N., Dadon S. B. -E., Zinal E., Berkovich Z., Abbo S., Reifen R. The potential use of chickpeas in development of infant follow-on formula. Nutrition Journal, 2014, vol. 13, no. 1, art. 8. https://doi.org/10.1186/1475-2891-13-8

14. Rachwa-Rosiak D., Nebesny E., Budryn G. Chickpeas - composition, nutritional value, health benefits, application to bread and snacks: a review. Critical Reviews in Food Science and Nutrition, 2015, vol. 55, no. 8, pp. 1137-1145. https://doi.org/10.1080/104 08398.2012 .687418

15. De Giovanni C., Pavan S., Taranto F., Di Rienzo V., Miazzi M. M., Marcotrigiano A. R., Mangini G., Montemurro C., Ricciardi L., Lotti C. Genetic variation of a global germplasm collection of chickpea (Cicer arietinum L.) including Italian accessions at risk of genetic erosion. Physiology and Molecular Biology of Plants, 2017, vol. 23, no. 1, pp. 197-205. https://doi.org/10.1007/ s12298-016-0397-4

16. Adamovska V. G., Molodchenkova O. O., Sichkar V. I., Kartuzova T. V., Levitsky Yu. A., Bezkrovna L. Ya. Biochemical characteristics of legumes genotypes of the South of Ukraine in the connection with the breeding for seed quality. Zbirnik naukovikh prats' Selektsiino-genetichnogo institutu - Natsional'nogo tsentru nasinneznavstva ta sortovivchennya [Collection scientific works of Institute of Breeding and Genetics - National Center for Variety Research and Seed Science]. Odessa, 2015, iss. 26 (66), pp. 107123 (in Ukrainian).

17. Puzik V. K., Titova A.E. Classification and separation of sources of qualitative composition of chick-pea collections by the content of protein and olive. Visnik Poltavs'koï derzhavnoï agrarnoï akademï = Bulletin of Poltava State Agrarian Academy, 2018, no. 2, pp. $24-29$ (in Ukrainian). https://doi.org/10.31210/visnyk2018.02.03

18. Vus N. O., Kobizeva L. N. Sources of the complex price signs for nuts selection. Biologiya ta valeologiya: zbirnik naukovikh prats' [Biology and valeology: a collection of scientific papers]. Kharkiv, 2018, iss. 20, pp. 11-16 (in Ukrainian).

19. Shah H. U., Khan U. L., Alam S., Shad A. A., Iqbal Z., Parveen S. Effect of home cooking on the retention of various nutrients of commonly consumed pulses in Pakistan. Sarhad Journal of Agricultural, 2011, vol. 27, no. 2, pp. 279-284.

20. Avola G., Patanè C., Barbagallo R. N. Effect of water cooking on proximate composition of grain in the three Sicilian chickpeas (Cicer arietinum L.). LWT - Food Science and Technology, 2012, vol. 49, no. 2, pp. 217-220. https://doi.org/10.1016/j. lwt.2012.07.004

21. Patanè C. Variation and relationships among nutritional traits in Sicilian genotypes of chickpea (Cicer arietinum L.). Journal of Food Quality, 2006, vol. 29, no. 3, pp. 282-293. https://doi.org/10.1111/j.1745-4557.2006.00074.x 
22. Dragičević V., Kratovalieva S., Dumanović Z., Dimov Z., Kravić N. Variations in level of oil, protein, and some antioxidants in chickpea and peanut seeds. Chemical and Biological Technologies in Agriculture, 2015, vol. 2, no. 1, art. 2. https://doi. org/10.1186/s40538-015-0031-7

23. Özer S., Karaköy T., Toklu F., Baloch F. S., Kilian B., Özkan H. Nutritional and physicochemical variation in Turkish kabuli chickpea (Cicer arietinum L.) landraces. Euphytica, 2010, vol. 175, no. 2, pp. 237-249. https://doi.org/10.1007/s10681-010-0174-3

24. Bulbula D. D., Urga K. Study on the effect of traditional processing methods on nutritional composition and anti nutritional factors in chickpea (Cicer arietinum). Cogent Food \& Agriculture, 2018, vol. 4, no. 1, art. 1422370. https://doi.org/10.1080/23311932 2017.1422370

25. Shah T. M., Iqbal Z., Asi M. R., Atta B. M. Induced genetic variability for fatty acids and oil contents in chickpea (Cicer arietinum). International Journal of Agriculture and Biology, 2013, vol. 15, no. 3, pp. 419-426.

26. Zia-Ul-Haq M., Ahmad M., Iqbal S., Ahmad S., Ali H. Characterization and compositional studies of oil from seeds of desi Chickpea (Cicer arietinum L.) cultivars grown in Pakistan. Journal of the American Oil Chemists' Society, 2007, vol. 84, no. 12, pp. 1143-1148. https://doi.org/10.1007/s11746-007-1136-3

27. Singhai B., Shrivastava S. K. Nutritive value of new chickpea (Cicer arietinum) varieties. Journal of Food, Agriculture and Environment, 2006, vol. 4, no. 1, pp. 48-53.

28. Frimpong A. A study of chickpea (Cicer arietinum L.) seed starch concentration, composition and enzymatic hydrolysis properties. A Thesis for the degree of doctor of philosophy. Saskatoon, Saskatchewan, 2010. $151 \mathrm{p}$.

29. Nobile C. G. M., Carreras J., Grosso R., Inga M., Silva M., Aguilar R., Allende M. J., Badini R., Martinez M. J. Proximate composition and seed lipid components of "kabuli"-type chickpea (Cicer arietinum L.) from Argentina. Agricultural Sciences, 2013, vol. 4, no. 12, pp. 729-737. http://dx.doi.org/10.4236/as.2013.412099

\section{Information about authors}

Nadiia A. Vus - Ph. D. (Agricultural). Plant Production Institute named after V. Ya. Yuriev of NAAS (142 Moskovskyi Ave., Kharkiv 61061, Ukraine). E-mail: vus.nadezhda@gmail. com. http://orcid.org/0000-0001-7098-9158

Antonina A. Vasylenko - Ph. D. (Agricultural). Breeding Legume Crops Plant Production Institute named after V. Ya. Yuriev of NAAS (142 Moskovskyi Ave., Kharkiv 61061, Ukraine). E-mail: avase2015@gmail.com. http://orcid.org/00000003-0081-5894

Lyubov N. Kobyzeva - D. Sc. (Agricultural). Plant Production Institute named after V. Ya. Yuriev of NAAS (142 Moskovskyi Ave., Kharkiv 61061, Ukraine). E-mail: 1.n.kobyzeva@gmail. com. http://orcid.org/0000-0003-3067-7971.

Olha V. Besuhla - Ph. D., (Agricultural). Plant Production Institute named after V. Ya. Yuriev of NAAS (142 Moskovskyi Ave., Kharkiv 61061, Ukraine). E-mail: izhikolga@mail.ru. http://orcid.org/0000-0002-1458-1630

Olha V. Antziferova - Institute named after V. Ya. Yuriev of NAAS (142 Moskovskyi Ave., Kharkiv 61061, Ukraine). E-mail: antsyferova.olya@gmail.com. http://orcid.org/0000-0002-14661294

Serhii I. Sylenko - Ph. D. (Agricultural). Ustymivska Experimental station of the Plant Production, Institute named after V. Ya. Yuriev of NAAS (15 Akademika Vavilova Str., Ustymivka village 39074, Hlobyno District, Poltava Region, Ukraine). E-mail: s.sylenko@ukr.net. http://orcid.org/00000001-7248-5463

\section{Информация об авторах}

Вус Надежда Алексеевна - кандидат сельскохозяйственных наук, ведущий научный сотрудник лаборатории генетических ресурсов зернобобовых и крупяных культур, Институт растениеводства им. В. Я. Юрьева Национальной академии аграрных наук Украины (пр. Московский, 142, 61061 Харьков, Украина). E-mail: vus.nadezhda@gmail.com. http://orcid.org/0000-0001-7098-9158

Василенко Антонина Александровна - кандидат сельскохозяйственных наук, старший научный сотрудник, ведущий научный сотрудник лаборатории селекции зернобобовых культур, Институт растениеводства им. В.Я. Юрьева Национальной академии аграрных наук Украины (пр. Московский, 142, 61061 Харьков, Украина). E-mail: avase2015@gmail.com. http://orcid.org/0000-0003-0081-5894

Кобызева Любовь Никифоровна - доктор сельскохозяйственных наук, старший научный сотрудник, исполняющий обязанности директора, Институт растениеводства им. В.Я. Юрьева Национальной академии аграрных наук Украины (пр. Московский, 142, 61061 Харьков, Украина). E-mail: 1.n.kobyzeva@gmail.com. http://orcid.org/0000-00033067-7971

Безуглая Ольга Николаевна - кандидат сельскохозяйственных наук, старший научный сотрудник, заведующий лаборатории генетических ресурсов зернобобовых и крупяных культур, Институт растениеводства им. В.Я. Юрьева Национальной академии аграрных наук Украины (пр. Московский, 142, 61061 Харьков, Украина). E-mail: izhikolga@mail.ru. http://orcid.org/0000-0002-1458-1630

Анциферова Ольга Васильевна - младший научный сотрудник лаборатории генетики, биотехнологии и качества, Институт растениеводства им. В.Я. Юрьева Национальной академии аграрных наук Украины (пр. Московский, 142, 61061 Харьков, Украина). E-mail: antsyferova.olya@gmail.com. http://orcid.org/0000-0002-1466-1294

Силенко Сергей Иванович - кандидат сельскохозяйственных наук, старший научный сотрудник лаборатории зернобобовых, крупяных культур и кукурузы, Устимовская опытная станция Института растениеводства им. В.Я. Юрьева Национальной академии аграрных наук (ул. Академика Вавилова, 15, 39074 с. Устимовка, Глобинский p-н, Полтавская обл., Украина). E-mail: s.sylenko@ukr.net. http://orcid.org/0000-0001-7248-5463 